\title{
Molecular Studies on E.coli Isolate from Milk of Mastatic Cattle with Special Reference to Associated Biochemical Changes in Kaliobea Governorate
}

\author{
Mervat E.I. Radwan ${ }^{1, *}$, Khiary Farouk Abo-Zaid ${ }^{2}$ \\ ${ }^{1}$ Infectious Diseases Department with Veterinary Hospital, Faculty of Veterinary Medicine, \\ Benha University, Moshtohor, Toukh, Egypt \\ ${ }^{2}$ Serological Unit and Bacteriological Strains Bank of Enterobacteiacae Department, \\ Animal Health Research Institute (AHRI), Giza, Egypt \\ *Corresponding author: Dr_mervat19@yahoo.com
}

\begin{abstract}
This investigation was performed in Teaching hospital and farm of Benha university in Moshtohor the number of cows in this farm 80 dairy cows that 40 of them had clinical signs of mastitis (inflammation in teats, pain in milking and milk decrease in amount and quality). When examine these cows to identify the disease which cause these signs. California Mastitis Test (CMT) was performed to determine positive milk samples in the Mastitic targeted cows. 20 samples of early lactation stage cows out of 40 samples recovered from CMT- positive milk samples. Biochemical and PCR tests were performed to isolates E. Coli from positive milk samples (CMT) and determined three virulance genes, eae gene, SXT1 and SXT2. The significance of Escherichia coli-induced mastitis and biochemical changes associated to it in cows, due to the presence of virulence genes and wide range resistance to 20 antimicrobials, is concluded. E.coli cause biochemical changes in mastatic cow as (liver enzymes AST, GPT, TP, ant. oxidative enzymes as CAT, SOD, GST, LD and kidney function as urea and creatinine. E.coli has effect on inflammatory response in immunity system of mastitic cow by increase IL6, TNF and CRP.
\end{abstract}

Keywords: mastitis, serotyping characterization, PCR and biochemical alteration

Cite This Article: Mervat E.I. Radwan, and Khiary Farouk Abo-Zaid, "Molecular Studies on E.coli Isolate from Milk of Mastatic Cattle with Special Reference to Associated Biochemical Changes in Kaliobea Governorate.” American Journal of Infectious Diseases and Microbiology, vol. 5, no. 3 (2017): 115-119. doi: 10.12691/ajidm-5-3-4.

\section{Introduction}

Mastitis is an inflammation of the mammary glands associated with physical an-d chemical and microbiological changes. It is considered the most important disease in dairy herds [1]. The most important causitave environmental mastitis pathogen is E.coli [2]. Escherichia coli is a major etiological agent of intra-mammary infections (IMI) in cows, leading to acute mastitis and causing great economic losses in dairy production worldwide [3]. Particular strains cause persistent IMI, leading to recurrent mastitis. Virulence factors of mammary pathogenic E. coli (MPEC) involved pathogenesis of mastitis as well as those differentiating strains causing acute or persistent mastitis [4]. The infection occur after bacteria entrance mammary gland via teat canal, overcoming anatomical battier so they must evade the cellular and humeral defence mechanism of mammary gland to establish disease [5,6]. Limited number of E.coli strains has ability to adhere and invade bovine mammary epithelial cell[s and cause persistant infection, have severa 1 fimberia and fimberial adhesion that mediat adhesion to host epithelial cell through cell surface $[7,8]$. This study was performed to :Detection the causitive agent of clinical matitis in cow by isolation of E.coli from milk of mastatic cow with special refrence to biochemical changes associated to it in infected cow. Charactarization of E.coli pathogen isolated from mastatic cow biochemical and serlogicaly. Investigation of some virulance factor associated to E.coli isolates. Detection of E.coli attaching and enffacing (Intimin) eaeA, STX1 and STX2 virulence factors of E. coli comprise adhesins, which help the bacteria to adhere to and colonize mucosal surfaces, and toxins, which are proteins with the ability to disturb or modify the normal function of the host cell and to help the bacteria to cross the epithelial barrier and to invade the tissue [9]. Clinical E. coli mastitis can range from mild with only local signs to severe disease with systemic clinical signs. In severe cases the outcome can be acute tissue damage and complete loss of milk production or even the death of the diseased cow The severity of E. coli mastitis depends on the age of the cow and on the lactation stage, i.e. older cows and cows in early lactation are more susceptible to infection [10].

The general aim of this study was 1-To investigate host response to Escherichia coli infection represented in biochemical changes and immunity system reponse 2-To identify possible specific virulence genes and phylogeny types of E. coli associated with severity of clinical mastitis and the intramammary infection. 


\section{Material and Methods}

\subsection{Samples}

A total 40 of milk samples were collected from clinically mastatic cows from Quliobea governorate all samples collected in sterile screw martins and perform (CMT) the positive samples will send as soon as possible to lab to be examined. Bacteriological examination of milk samples [11] the collected samples were incubate aerobically at $37^{\circ} \mathrm{C}$ for $18-24 \mathrm{hrs}$ then centrifuged at $3000 \mathrm{rpm} / 20 \mathrm{~min}$ the cream and supernatant layer were discarded and streak the sediment on blood agar, maconcky agar and EMBagar. The plates were incubated aerobically at $37^{\circ} \mathrm{C}$ for $24-48 \mathrm{hrs}$ and examined for bacteriological growth. Suspected colonies appeared on different media were picked up and purified by subculture on fresh set of protective and preserved into semisolid agar for Identification of isolated m.o. According to colonial morphological and appearance, growth characterization, hemolytic patterns, microscopically by Gram stain and biochemically changes according to [12]

1-Morphologically

2-Biochemically identification

$\begin{array}{ll}\text { 1-Catalase } & \text { 2-Oxidase } \\ \text { 3-TSI } & \text { 3-Urease } \\ \text { 5-Indole } & \text { 6-MR } \\ \text { 7-VR } & \text { 8-Citrate } \\ \text { 9-Nitrate } & \text { 10-Sugar fermentation }\end{array}$

3-Serological identification according to [13]

4-PCR molecular identification

DNA extraction. DNA extraction from samples was performed using the QIAamp DNA Mini kit (Qiagen, Germany, GmbH) with modifications from the manufacturer's recommendations. Briefly, $200 \mu \mathrm{l}$ of the sample suspension was incubated with $10 \mu \mathrm{l}$ of proteinase $\mathrm{K}$ and $200 \mu \mathrm{l}$ of lysis buffer at $56^{\circ} \mathrm{C}$ for $10 \mathrm{~min}$. After incubation, $200 \mu \mathrm{l}$ of $100 \%$ ethanol was added to the lysate. The sample was then washed and centrifuged following the manufacturer's recommendations. Nucleic acid was eluted with $100 \mu \mathrm{l}$ of elution buffer provided in the kit.

\subsection{Oligonucleotide Primer}

Primers used were supplied from Metabion (Germany) are listed in Table 3 PCR amplification. Primers were utilized in a $25 \mu \mathrm{l}$ reaction containing $12.5 \mu \mathrm{l}$ of
EmeraldAmp Max PCR Master Mix (Takara, Japan), $1 \mu \mathrm{l}$ of each primer of $20 \mathrm{pmol}$ concentration, $4.5 \mu \mathrm{l}$ of water, and $6 \mu \mathrm{l}$ of DNA template. The reaction was performed in an Applied biosystem 2720 thermal cycler. For stx1,2 duplex PCR, primers were utilized in a 50- $\mu$ l reaction containing $25 \mu \mathrm{l}$ of EmeraldAmp Max PCR Master Mix, 1 $\mu \mathrm{l}$ of each primer of $20 \mathrm{pmol}$ concentration, $13 \mu \mathrm{l}$ of water, and $8 \mu \mathrm{l}$ of DNA template.

\subsection{Analysis of the PCR Products}

The products of PCR were separated by electrophoresis on 1.5\% agarose gel (Applichem, Germany, GmbH) in $1 \mathrm{xTBE}$ buffer at room temperature using gradients of $5 \mathrm{~V} / \mathrm{cm}$. For gel analysis, $20 \mu \mathrm{l}$ of each PCR product were loaded in each gel slot. A Generuler 100 bp ladder (Fermentas, Thermo Scientific, Germany) was used to determine the fragment sizes. The gel was photographed by a gel documentation system (Alpha Innotech, Biometra) and the data was analyzed through computer software.

\section{Result}

Table 1 explain Primers sequences, target genes, amplicon sizes and cycling conditions which used in preparation of DNA, Our results in Table 2 and Table 3 showed that Characterization of E.coli isolated from mastatic milk by chemical tests which diffrantiation it from other cause of mastitis and other enterobactereacae, Table 2 determine strain of E.coli by Serotypes of E.coli isolated from clinical mastitis cow. Table 4 showed that virulant genes present in strains O44eae, O44eaeand Stx1, O55, O26eae, O114, O146 eae and Stx2, O158, O125. From begaining of Table 5 and Table 6 table biochemical changes associated to infection appear in cows that infected with mastitis Table 5: showed biochemical changes associated to E.coli infection in serum of cows while Table 6: showed inflamatory response associated to E.Coli infection and immunity response. Figure 1 showed abnormal changes in teat infected with E.coli showed inflamed and redness teat when compare with normal teat in other figure while Figure 2: agrose gel electrophoresis showed Intamin (eaeA, Stx1 and Stx2) genes from extracted DNA of E.coli serogroup (O55, O26, O114, O146 O158, and O125).

Table 1. Primers sequences, target genes, amplicon sizes and cycling conditions

\begin{tabular}{|c|c|c|c|c|c|c|c|c|}
\hline \multirow{2}{*}{$\begin{array}{l}\text { Target } \\
\text { gene }\end{array}$} & \multirow{2}{*}{$\begin{array}{c}\text { Primers sequences } \\
5^{\prime}-3^{\prime}\end{array}$} & \multirow{2}{*}{$\begin{array}{l}\text { Amplified } \\
\text { segment } \\
\text { (bp) }\end{array}$} & \multirow{2}{*}{$\begin{array}{c}\text { Primary } \\
\text { Denaturation }\end{array}$} & \multicolumn{3}{|c|}{ Amplification (35 cycles) } & \multirow{2}{*}{$\begin{array}{c}\text { Final } \\
\text { extension }\end{array}$} & \multirow{2}{*}{ Reference } \\
\hline & & & & $\begin{array}{c}\text { Secondary } \\
\text { denaturation }\end{array}$ & Annealing & Extension & & \\
\hline \multirow{2}{*}{ eaeA } & ATGCTTAGTGCTGGTTTAGG & \multirow{2}{*}{248} & \multirow{2}{*}{$\begin{array}{l}94^{\circ} \mathrm{C} \\
5 \mathrm{~min} .\end{array}$} & \multirow{2}{*}{$\begin{array}{l}94^{\circ} \mathrm{C} \\
30 \mathrm{sec} .\end{array}$} & \multirow{2}{*}{$\begin{array}{c}51^{\circ} \mathrm{C} \\
30 \mathrm{sec} .\end{array}$} & \multirow{2}{*}{$\begin{array}{c}72^{\circ} \mathrm{C} \\
30 \mathrm{sec} .\end{array}$} & \multirow{2}{*}{$\begin{array}{l}72^{\circ} \mathrm{C} \\
7 \mathrm{~min} .\end{array}$} & \multirow{2}{*}{ [14] } \\
\hline & GCCTTCATCATTTCGCTTTC & & & & & & & \\
\hline \multirow{2}{*}{ Stx 1} & ACACTGGATGATCTCAGTGG & \multirow{2}{*}{614} & \multirow{4}{*}{$\begin{array}{l}94^{\circ} \mathrm{C} \\
5 \mathrm{~min} .\end{array}$} & \multirow{4}{*}{$\begin{array}{l}94^{\circ} \mathrm{C} \\
30 \mathrm{sec} .\end{array}$} & \multirow{4}{*}{$\begin{array}{c}58^{\circ} \mathrm{C} \\
45 \mathrm{sec} .\end{array}$} & \multirow{4}{*}{$\begin{array}{r}72^{\circ} \mathrm{C} \\
45 \mathrm{sec} .\end{array}$} & \multirow{4}{*}{$\begin{array}{c}72^{\circ} \mathrm{C} \\
10 \mathrm{~min}\end{array}$} & \multirow{4}{*}[15]{} \\
\hline & CTGAATCCCCСТCСАTTATG & & & & & & & \\
\hline \multirow{2}{*}{ Stx2 } & CCATGACAACGGACAGCAGTT & \multirow{2}{*}{779} & & & & & & \\
\hline & CCTGTCAACTGAGCAGCACTTTG & & & & & & & \\
\hline
\end{tabular}


Table 2. Characterization of E.coli isolated from mastatic milk

\begin{tabular}{|l|l|l|}
\hline Test & Reaction & + Ve \\
\hline Gram stain & Gram -Ve medium size bacilli & $100 \%$ \\
\hline Biochemical Identification & & \\
\hline 1-catalase & Gas bubbles & $100 \%$ \\
\hline 2-Oxidase & -Ve & $0 \%$ \\
\hline Indol & Red ring & $100 \%$ \\
\hline 3-MR & Red colour & $100 \%$ \\
\hline 4-VR & -Ve & $0 \%$ \\
\hline 5-S.Citrate & - Ve & $0 \%$ \\
\hline 6-Urease & -Ve & $0 . \%$ \\
\hline 7-Tsi & A/A/gas+H -H2S & $100 \%$ \\
\hline
\end{tabular}

Table 3. Serotypes ofE.coli isolated from clinical mastitis cow

\begin{tabular}{|c|c|c|c|}
\hline Noumber of mastatic cows & Serotypes & Noumber & Percent \\
\hline \multirow{8}{*}{20} & $\mathrm{O} 44$ & 4 & $20 \%$ \\
\hline & O55 & 3 & $15 \%$ \\
\hline & $\mathrm{O} 111$ & 2 & $10 \%$ \\
\hline & $\mathrm{O} 124$ & 2 & $10 \%$ \\
\hline & $\mathrm{O} 114$ & 2 & $10 \%$ \\
\hline & $\mathrm{O} 158$ & 2 & $10 \%$ \\
\hline & O125 & 3 & $15 \%$ \\
\hline & O26 & 2 & $10 \%$ \\
\hline
\end{tabular}

Table 4. Characterization of E.coli serogroup isolates recovered from milk samples of mastatic cow byPCR assays for Intamin, Stx1 and Stx2

\begin{tabular}{|c|c|c|c|c|}
\hline \multirow{2}{*}{ Sample No. } & \multirow{2}{*}{ Sample ID } & \multicolumn{3}{|c|}{ Results } \\
\cline { 3 - 5 } & & eaeA & Stx1 & Stx2 \\
\hline 1 & O44 & + & - & - \\
\hline 2 & O44 & + & - & - \\
\hline 3 & O55 & - & - & - \\
\hline 4 & O26 & - & - & - \\
\hline 5 & O114 & + & - \\
\hline 6 & O146 & - & - \\
\hline 7 & O158 & - & - & - \\
\hline 8 & O125 & & & - \\
\hline
\end{tabular}

Table 5. Biochemical changes associated to E.coli infection in serum of cows * value of $\mathbf{p}<0.01$ and ** value of $\mathbf{p}<0.001$

\begin{tabular}{|c|c|c|c|c|c|c|c|c|c|c|c|}
\hline $\begin{array}{c}\text { G Groups } \\
\text { Parameters }\end{array}$ & CAT & SOD & LDH & ALP & TP & CREATINE & GOT & GST & GPT & UREA & MDA \\
\hline $\begin{array}{c}\text { CONTROL } \\
\text { negative groups }\end{array}$ & $\begin{array}{c}50.00 \\
\pm 4.103\end{array}$ & $\begin{array}{c}41.00 \pm . \\
512\end{array}$ & $\begin{array}{c}43.50 \\
\pm .272\end{array}$ & $\begin{array}{c}4.545 \pm . \\
169\end{array}$ & $\begin{array}{c}8.463 \\
\pm .224\end{array}$ & $\begin{array}{c}0.5225 \\
\pm 0.04715\end{array}$ & $\begin{array}{c}56.50 \pm . \\
331\end{array}$ & $\begin{array}{c}241.0 \pm \\
6.24\end{array}$ & $\begin{array}{c}18.75 \pm . \\
287\end{array}$ & $\begin{array}{c}24.50 \pm . \\
661\end{array}$ & $\begin{array}{c}64.50 \pm \\
4.252\end{array}$ \\
\hline $\begin{array}{c}\text { E.coli } \\
\text { Infected groupa }\end{array}$ & $\begin{array}{c}19.83 \pm 1 . \\
470^{* *}\end{array}$ & $\begin{array}{c}16.67 \\
\pm 1.085^{* *}\end{array}$ & $\begin{array}{c}115.6 \\
\pm 8.721^{* *}\end{array}$ & $\begin{array}{c}3.513 \pm \\
0.116^{*}\end{array}$ & $\begin{array}{c}6.428 \pm \\
0.1523^{* *}\end{array}$ & $\begin{array}{c}1.370 \\
\pm 0.1610^{*}\end{array}$ & $\begin{array}{c}81.40 \pm \\
8.68^{* *}\end{array}$ & $\begin{array}{c}156.0 \pm \\
5.310^{* *}\end{array}$ & $\begin{array}{c}53.20 \pm \\
3.137^{* *}\end{array}$ & $\begin{array}{c}44.67 \pm \\
3.252^{* *}\end{array}$ & $\begin{array}{c}139.6 \pm 6.2 \\
58^{* *}\end{array}$ \\
\hline
\end{tabular}

Table 6. In study Van ELISA for the quantitation of bovine TNF- $\alpha$ in plasma (Carstensen et al., 2005)16 was modified for serum as described in Lehtolainen et al. (2004). The detection limit of the ELISA was $0.5 \mathrm{ng} / \mathrm{ml}$ for the serum

\begin{tabular}{|l|c|c|}
\hline Parameters & Control negative & E.coli infected \\
\hline IL6 & $81.50 \pm 5.362$ & $136.2 \pm 6.320^{*}$ \\
\hline TNF & $33.25 \pm 2.0564$ & $72.67 \pm 6.412^{*}$ \\
\hline CRP & $20.25 \pm 3.568$ & $96.00 \pm 6.261^{*}$ \\
\hline
\end{tabular}

* value of $\mathrm{p}<0.01$. 


\section{Mastitis in cattle}

Mastatic udder and teats are asymmetric , infected quarter is inflamed and enlarged in size

\author{
Normal udder and teats are symmetric \\ four quarter are equal in size
}

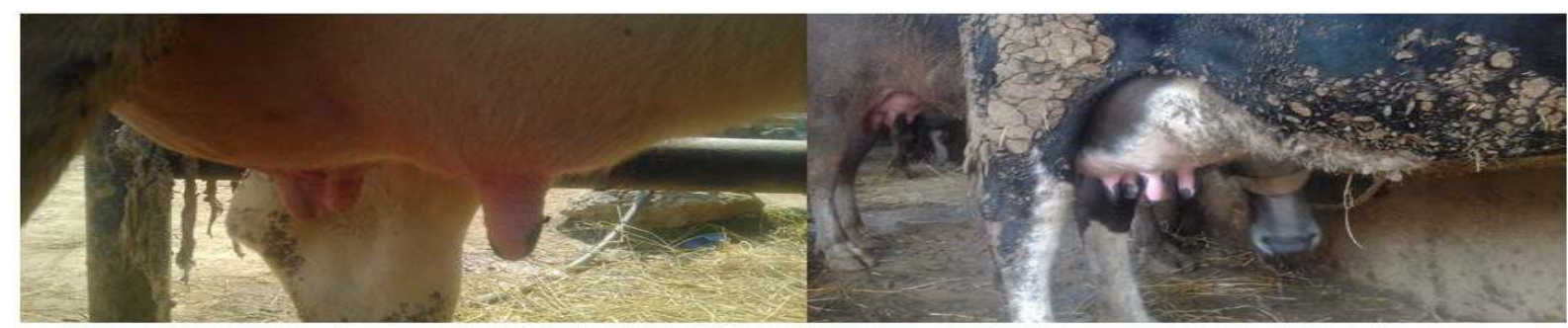

Figure 1.

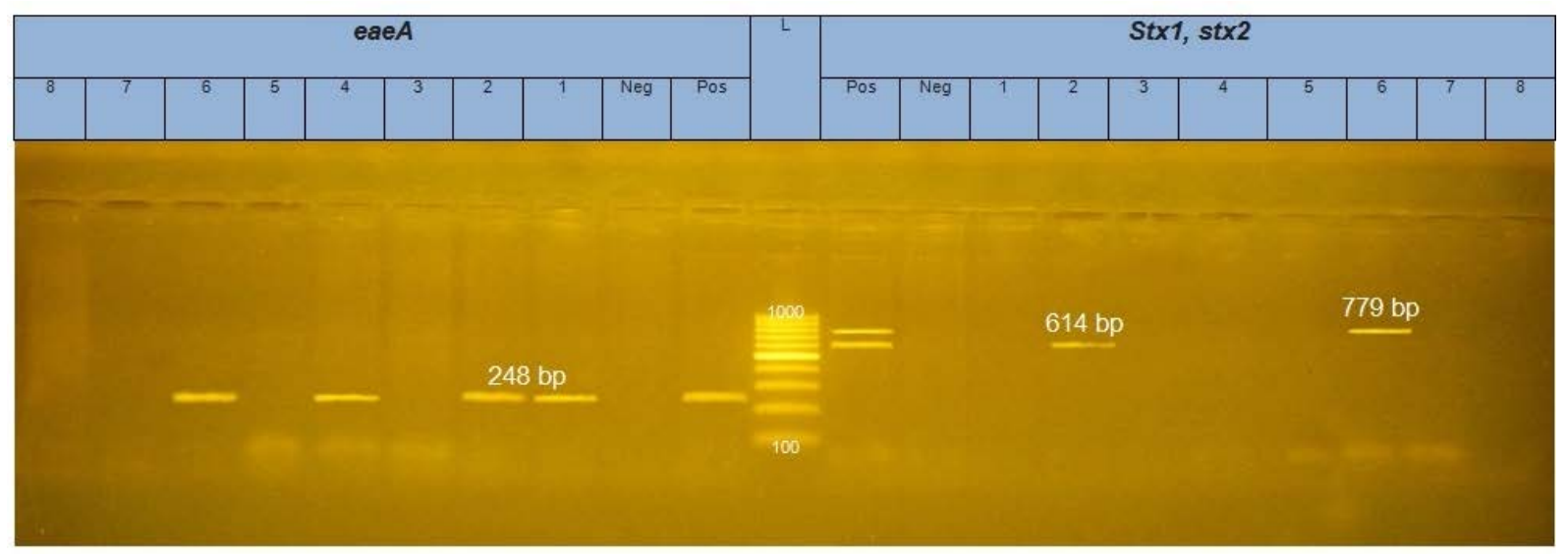

Figure 2.

\subsection{Statistical Analysis}

The statistics was applied by means of SPSS soft ware (SPSS ver. 16, Inc., [17])

\section{Discussion}

The significance of Escherichia coli-induced mastitis in cows, associated with the presence of virulence genes, this targeted surveillance of rural dairy farms confirmed the significance of E. coli infection in mastitis of cows [18] Escherichia coli is a major etiological agent of intramammary infections (IMI) in cows, leading to acute mastitis and causing great economic losses in dairy production worldwide [19]. Our result concluded that E.coli is the most cause of mastities by feild diagnosis CMT found 20 out of 40 samples the causitive agent of mastities was pathogenic E.coli and confirmed by charachtarization of E.coli and biochemical analysis to determined strain of E.coli. This aforesaid results came in agreement with other reports which recorded that E. coli is among the most common infectious agents isolated from severe mastitis cases in modern dairy farms [20,21]. The California Mastitis Test (CMT) provided a useful tool for farmers and veterinarians for measuring the level of inflammation in the udder [22]. In current study founded increase in inflamatory parameters IL6, TNF and CRP factors, In our opinion, this elevation may be created as a result of proinflamatory response to infection with E.coli and stmulation of immunity system, these aforesaid results came in agreement with other reports recoreded that LPS triggers formation of proinflammatory and inflammatory cytokines, produced predominantly by monocytes and macrophages [23,24]. Cytokines, such as tumor necrosis factor alpha (TNF- $\alpha$ ), initiate the inflammatory response [25], which induces the acute phase response (APR) by activating the production of acute phase proteins (APP) and LPS-binding protein (LBP) [26,27,28,29]. All the above mentioned alterations mainly have a drawback effect on the biochemical and oxidative serum constituents specially SOD, LDH, ALB, TP, CREATINE, GOT, GST, GPT, Urea and MDA, these factors were cows-dependent, like the speed of the inflammatory response, lactation stage and age of the cow, are thought to determine the severity of E. coli mastitis [4]. The study advanced our standing of the mastatic effect of E.coli on cows. E.coli virulance genes That detected by PCR were Itamin, SxT1 and SxT2 these toxins were isolated from strains (O44, O55, O111, O124, O114, O158, O125, O26) were considered as very important virulant factors of E.coli. Most of the pathogenic E. coli possesses several kinds of pathogenic mechanisms and virulence factors. Intimin is a protein encoded by eae gene [30]. It facilitates the adherence of attaching and effacing E. coli to the epithelial cells. It is proven that the eae gene in E. coli plays a definite role in induction of cattle mastitis [31] also this result came agree with [9] who concluded that 
virulence factors of E. coli comprise adhesins, which help the bacteria to adhere to and colonize mucosal surfaces, and toxins, which are proteins with the ability to disturb or modify the normal function of the host cell and to help the bacteria to cross the epithelial barrier and to invade the tissue. There was a clear significant correlation between the CMT scores and the E. Coli, The presence of eae Intimin gene in E. coli involved in mastitis of dairy cows is of paramount importance, E. coli with Intimin gene are able to form small microcolonies on the surface of infected epithelial cells, followed by localized degeneration of the microvilli cumulating in an attaching and effacing (A/E) [18]. all the E. coli isolates with the virulence genes stx and eae showed resistance to a higher number of antimicrobials than those which were stx-negative [30]. It is recommended in disease-control programs of dairy to study the E. coli involvement in mastitis, and to include in the surveillance the detection of virulence genes that are decisive in economic losses in vetrinarian.

\section{Acknowledgements}

Education hospital of Vet. Med. Banha University where the experiment was performed and special acknowledgement for all members of Vet. Med. Department and Head of Department, Prof. Dr. Mohamed Ghanem.

\section{References}

[1] Acik, M.N., Yurdakul N.E., akici L. C, Onat N., Dogan,€O., etinkaya B. C. 2004. traT and CNF2 genes of Escherichia coli isolated from milk of healthy cows and sheep. Department of Microbiology, Faculty of Veterinary Medicine, University of Firat, 23119 Elazig, Turkey

[2] Mokovee, J.A Ruegge, P.L. (2003). Results of milk samples submitted for microbiological examination in Wisconsin from 1994 to 2001 J.Dairy Sci. , 86:3466-3472.

[3] Blum SE1, Heller ED2, Sela S3, Elad D4, Edery N5, Leitner G6. 2015. Genomic and Phenomic Study of Mammary Pathogenic Escherichia coli. PLoS One. Sep 1; 10(9): e0136387.

[4] Burvenich, C., Van Merris, V., Mehrzad, J., Diez-Fraile, A., Duchateau, L., 2003. Severity of E. coli mastitis is mainly determined by cow factors. Vet. Res. 34, 521-564.

[5] Radostits OM, Gay CC, Hinchcliff KW, Constable PD (2007). Diseases caused by fungi. Veterinary Medicine: A textbook of the diseases of cattle, horses, sheep, pigs and goats. 10th edition. Saunders Elsevier Ltd. Philadelphia, USA. pp. 842-860.

[6] Mbuk, E. U.1, Kwaga, J. K. P.1, Bale, J. O. O.2, Boro, L. A.3 and Umoh, J. U. 2016, Coliform organisms associated with milk of cows with mastitis and their sensitivity to commonly available antibiotics in Kaduna State, Nigeria Journal of Vetrinary Mediciny and Animal Healthy Vol. 8(12), pp. 228-236, December.

[7] MILANOV Dubravka, PRUNIĆ Bojana, VELHNER Maja, TODOROVIĆ Dalibor, POLAČEK Vladimir 2015, INVESTIGATION OF BIOFILM FORMATION AND PHYLOGENETIC TYPING OF ESCHERICHIA COLI STRAINS ISOLATED FROM MILK OF COWS WITH MASTITIS, Acta Veterinaria-Beograd 65 (2), 202-216.

[8] Döpfer, D., Almeida, R.A., Lam, T.J.G.M., Nederbragt, H., Oliver, S.P. and Gaastra, W., 2000. Adhesion and invasion of Escherichia coli from single and recurrent clinical cases of bovine mastitis in vitro. Vet. Microbiol. 74, 331-343.

[9] Kaper, J.B., Nataro, J.P., Mobley, H.L., 2004. Pathogenic Escherichia coli. Nat. Rev. Microbiol. 2, 123-140.

[10] Mehrzad, J., Duchateau, L., Pyörälä, S., Burvenich, C., 2002. Blood and milk neutrophils chemiluminescence and viability in primiparous and pluriparous dairy cows during late pregnancy, around parturition and early lactation. J. Dairy Sci. 85, 3268-3276.
[11] Qurnn P.J.: Morky, B.K Cater M.E. Donelly W.J.C. and Leonard F.C. (2002). 8 Vetrinary Microbiology and Microbial diseases. $1^{\text {st }}$ Low stat University Press Blackwell Science

[12] Boerlin P. Kuhnert, P. Hussy. D. and Schaellibaum, M. 2003) Methods of identification of S.aureus isoletes in cases of bovine mastitis J.Clin.Microbial. 41(2): 767-771.

[13] Edwered P.R. and Ewing W.H. (1972). Identification of Enterobacteriaceae. Burrgess pubi, Co., Minneapolis, Minnesota, 103-104.

[14] Bisi-Johnson, M.A.; Obi, C.L.; Vasaikar, S.D.; Baba, K.A. and Hattori, T. (2011). Molecular basis of virulence in clinical isolates of Escherichia coli and Salmonella species from a tertiary hospital in the Eastern Cape, South Africa. Gut Pathogens 2011, 3:9.

[15] Dipineto, L.; Santaniello, A.; Fontanella, M.; Lagos, K.; Fioretti, A. and Menna, L.F. (2006). Presence of Shiga toxin-producing Escherichia coli O157:H7 in living layer hens. Letters in Applied Microbiology 43 (2006) 293-295.

[16] Carstensen, L., Rontved, C.M., Nielsen, J.P., 2005. Determination of tumor necrosis factor-alpha responsiveness in piglets around weaning using an ex vivo whole blood stimulation assay. Vet Immunol. Immunopathol. 105, 59-66.

[17] Steel R, Torrie J, Dickey D (1997). Principles and procedures of Statistics: A Biometrical Approach, 3rd ed., McGraw-Hill, New York, NY.

[18] Elie K. Barbour,Tamar J. Kassabian, Houssam Shaib, Zeina Kassaify, Archana Iyer, Esam Azhar, Steve Harakeh, Taha Kumosan. (2015) The Significance of Escherichia coli-induced Mastitis in Cows Associated with the Presence of Virulence Genes and Wide Range-resistance to Twenty Antimicrobials

[19] Bradley AJ, Green MJ: 2001, Adaptation of Escherichia coli to the bovine mammary gland. Journal of Clinical Microbiology 39: 1845-1849.

[20] Bradley, A.J., Leach, K.A., Breen, J.E., Green, L.E., Green, M.J., 2007. Survey of the incidence and aetiology of mastitis in dairy farms in England and Wales. Vet. Rec. 160, 253-258.

[21] Bradley, A. 2002 Bovine mastitis an evolving disease, The vetrinary Journal 164, 116-128.

[22] Persson Waller, K., Colditz, I.G., Lun, S., Östensson, K., 2003. Cytokines in mammary lymph and milk during endotoxin-induced bovine mastitis. Res Vet Sci. 74, 31-6.

[23] Gonen, E., Vallon-Eberhard, A., Elazar, S., Harmelin, A., Brenner, O., Rosenshine, I., Jung, S., Shpigel, N., 2007. Toll-like receptor 4 is needed to restrict the invasion of Escherichia coli P4 into mammary gland epithelial cells in a murine model of acute mastitis. Cellular Microbiology.

[24] Paape, M., Bannerman, D., Zhao, X., Lee, J.W., 2003. The bovine neutrophil: +structure and function in blood and milk. Vet. Res. 34, 597-627.

[25] Bannerman, D.D., Paape, M.J., Hare, W.R., Sohn, E.J., 2003. Increased levels of LPS-binding protein in bovine blood and milk following bacterial lipopolysaccharide challenge. J. Dairy Sci. 86, 3128-3137.

[26] Bannerman, D.D., Paape, M.J., Lee, J.W., Zhao, X., Hope, J.C., Rainard, P., 2004. Escherichia coli and Staphylococcus aureus elicit differential innate immune responses following intramammary infection. Clin. Diagn. Lab. Immunol. 11, 463-472.

[27] Eckersall, P.D., Young, F.J., McComb, C., Hogarth, C.J., Safi, S., Weber, A., McDonald, T., Nolan, A.M., Fitzpatrick, J.L., 2001. Acute phase proteins in serum and milk from dairy cows with clinical mastitis. Vet. Rec. 148, 35-41.

[28] Hiss, S., Mielenz, M., Bruckmaier, R.M., Sauerwein, H., 2004. Haptoglobin concentrations in blood and milk after endotoxin challenge and quantification of mammary Hp mRNA expression. J. Dairy Sci. 87, 3778-3784.

[29] Ghanbarpour R, Oswald E. Phylogenetic distribution of virulence genes in Escherichia coli isolated from bovine mastitis in Iran. Res Vet Sci. 2010; 88:6-10.

[30] Correa MGP, Marin JM. O-serogroups, eae gene and EAF plasmid in Escherichia coli isolates from cases of bovine mastitis in Brazil. Vet Microbiol. 2002; 85:125-132.

[31] Solomakos N, Govaris A, Angelidis AS, Pournaras S, Burriel,AR, Kritas SK, Papageorgiou DK. Occurrence, virulence genes and antibiotic resistance of Escherichia coli O157 isolated from raw bovine, caprine and ovine milk in Greece. Food Microbiol. 2009; 26: 865-871. 